\title{
Comparison of Native Chinese-Speaking and Native English-Speaking Engineering Students' Information Literacy Challenges
}

\begin{abstract}
This study identifies challenges that native Chinese-speaking undergraduate engineering students face in researching and writing an academic paper in comparison with their native English-speaking peers. With growing enrolment of Chinese students in North America, the question of how best to enhance these students' learning experiences through library instruction and services is increasingly important. In this study, researchers recruited 17 participants (eight native Chinese-speaking and nine native English-speaking students) from a communication in engineering course at McGill University, and conducted a preliminary interview, an online survey, and an in-depth interview to gather data about each student's research experience. The online survey findings, which were used to inform the in-depth interview questions, were reported in a previous publication. The current article presents the qualitative findings from the in-depth interviews only. Findings show that native Chinese-speaking students have unique informationrelated challenges in the areas of searching, evaluating information, reading, writing, and citing. Challenges with specific elements of searching (such as locating full text) and writing (such as creating an outline) were shared among members of both groups. Recommendations for librarians, engineering instructors, and staff in other units serving international students are also provided.
\end{abstract}

\section{Keywords}

information literacy challenges; information literacy needs; library instruction; Chinese students; international students; undergraduate engineering students

\section{Introduction}

With growing enrolment of Chinese engineering students in North America, the question of how best to enhance these students' learning experiences through library instruction and services becomes increasingly important. This study identifies challenges that native Chinese-speaking undergraduate engineering students face in researching and writing an academic paper in comparison with native English-speaking students at McGill University in Montreal, Quebec. The researchers recruited 17 participants (eight native Chinese-speaking and nine native English-speaking students) from a communication in engineering course at McGill University, and conducted a preliminary interview, an online survey, and an in-depth interview to gather data about each student's research experience. The online survey findings, which were used to inform the in-depth interview questions, were reported in a previous publication entitled "Identifying challenges faced by Chinese undergraduate engineering students in acquiring information literacy skills" (Zhao \& Mawhinney, 2014). The current article reports on the qualitative findings from the in-depth interviews.

A rapidly growing portion of international students in Canada and the US are from China. As illustrated in Figure 1, Canada, the US, and McGill University have all seen substantial increases in the percentages of Chinese students over the past decade. In Canada, not only has China been the top source country for international students for the past decade, but also the number of Chinese students enrolled in Canadian institutions of higher education has soared from 39,954 in 2004 to 95,731 in 2013 for an increase of 140\% (Government of Canada, 2015). In the US, Chinese students currently account for $31 \%$ of all international students, the largest cohort from any given country having grown significantly from 62,523 in 2004/05 to 
274,439 in 2013/14, with an increase of $339 \%$ (Institute of International Education, 2015). At McGill University, the number of students from China has increased from 433 in 2004 to 1331 in 2014 (Enrolment Services, McGill University, 2015). The 141\% increase over the past decade parallels the increase of Chinese students for Canada as a whole (see Figure 1).

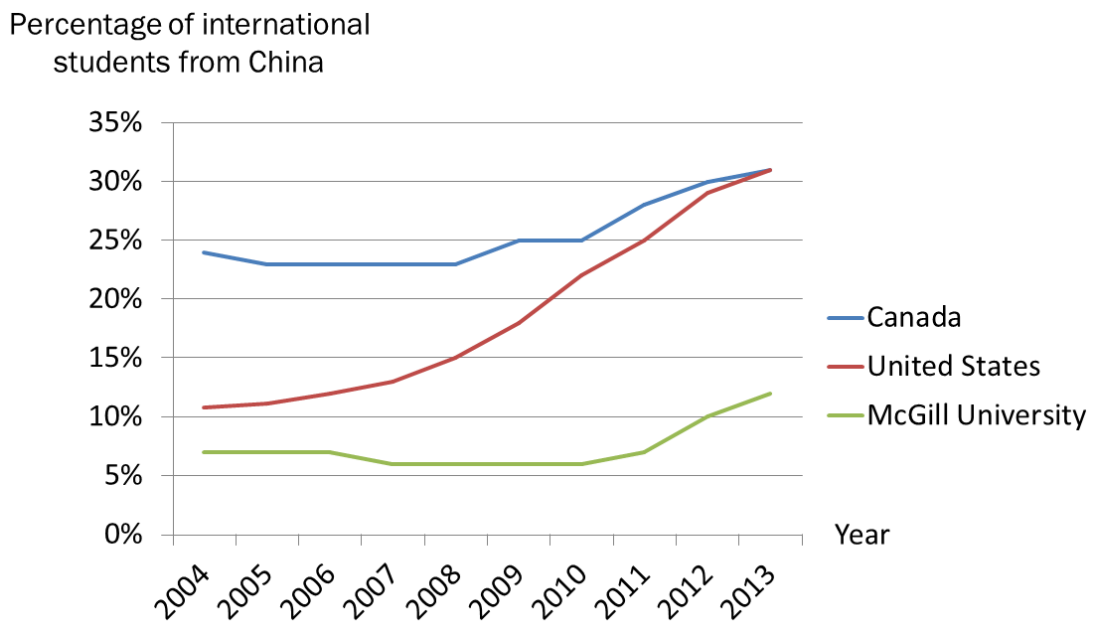

Figure 1. Percentage of international students from China by year, in Canada, in the U.S., and at McGill University. Generated using data from International students with a valid permit on December 31st by top 50 countries of citizenship, 2004 to 2013, by Government of Canada, 2015, Retrieved from www.cic.gc.ca/english/resources/statistics/facts2013/temporary/4-2.asp; Open doors data: Fast facts, by Institute of International Education, 2015, Retrieved from www.iie.org/Research-and-Publications/OpenDoors/Data/Fast-Facts; and Enrolment reports, by Enrolment Services, McGill University, 2015, Retrieved from http://www.mcgill.ca/es/registration-statistics

Many international students choose to study in the field of engineering. According to recent statistics, engineering is the second most popular field of study for international students in both Canada (Statistics Canada, 2011) and the US (Institute of International Education, 2014), with nearly $15 \%$ of international students in Canada studying engineering and $19 \%$ of international students doing so in the US. Combined with the increased number of Chinese students in engineering are increased expectations required of engineering students from accreditation boards. The Canadian Engineering Accreditation Board has established a set of attributes for undergraduate engineering students to possess before they graduate (Engineers Canada, 2014, pp. 13-14). Four out of the twelve graduate attributes - "investigation", "communication skills", "ethics and equity", and "life-long learning" - are closely associated with information literacy competencies. Similar student outcomes are also included in the Criteria for Accrediting Engineering Programs in the US (ABET, 2015). Given the rapid growth of Chinese engineering students in Canada and the US and the growing importance of attributes related to information literacy expected of engineering graduates, it is an integral part of librarians' and other educators' responsibilities to play an active role in equipping all students, regardless of their backgrounds, with these competencies.

\section{Background}

McGill University offers a course entitled "Communication in Engineering" (CCOM 206), which is required by most engineering programs. The course's objectives are for students to develop strategies "for generating, developing, organizing, and presenting ideas in a technical setting" and the course work consists of developing "academic, technical, and professional writing skills 
in engineering" (McGill University, 2015). Students in this course are required to complete a research paper where they must select an engineering problem, conduct a literature review, and write up their arguments in favor of a specific solution. Since most students take the course in their first or second year at McGill University, this course has provided a venue for librarians to integrate information literacy instruction into the engineering curriculum early on in students' programs. For the past several years, a team of science and engineering librarians (including both of the study researchers) have taught two library instruction sessions to each section of the course. The first session covers how to formulate a search strategy, find research materials using an engineering database, and use citation management software, and the second session provides instruction on how to read research articles efficiently and effectively.

Since there is a large cohort of students taking the course and all students must complete the same research assignment, CCOM 206 presented the possibility of gathering a sufficiently large number of participants from two distinct native-speaking language backgrounds (Chinese and English) and comparing their specific information literacy challenges. The course provides an ideal environment for exploring the challenges that students encounter during the research process since the experience of researching and writing the paper for CCOM 206 relates to nearly all types of information literacy competencies.

\section{Literature Review}

Most previous research concurs that international students face challenges in seeking and using information (Ishimura \& Bartlett, 2014; Liu \& Winn, 2009; Ramachandran, 2014; Sato \& Hodge, 2009; Hensley \& Love, 2011; Chen \& Van Ullen, 2011), including language barriers, general cultural adjustments, research and writing skills, and familiarity with library systems (Hensley \& Love, 2011; Ishimura \& Bartlett, 2014).

Language difficulties

The top reason for international students' challenges is language difficulties. As SarkodieMensah (1998) states, "There is hardly any study about international students in the US that does not mention language as the major problem" (p. 218). Language difficulties have further repercussions on students' learning such as loss of confidence and fear of academic failure (Sato \& Hodge, 2009, p. 144). As Ishimura and Bartlett (2014) state, "The first step to academic success is to understand assignment guidelines and professors' expectations for written work. However, lower English proficiency may prevent students from deciphering their own research needs in relation to assignment requirements" (p. 314). Language difficulties not only affect student understanding of assignments but also influence their willingness to seek help. International students may avoid using reference services because they are "afraid of [their] English not being good enough," have a fear of "asking stupid questions" and are "afraid of not understanding answers" (Liu \& Redfern, 1997, p. 353). Trew (2006) also notes that language difficulties can inhibit international students from understanding library jargon and using their associated services (e.g. interlibrary loan) (p. 151). Previous literature shows that international students' language difficulties may result in them losing confidence, being fearful of asking questions, and underutilizing services.

Although previous literature reports that both native speaking and international students have difficulty finding information (Varga-Atkins \& Ashcroft, 2004, p. 48), it also suggests that the linguistic disadvantages that international students face translate into increased challenges, especially related to creating search strategies. Ishimura and Bartlett (2014) note specific areas of difficulty as being: keyword selection, using plural forms, synonyms, and correct spellings ( $p$. 
314), as well as selecting terminology (Ishimura \& Bartlett, 2013). Trew (2006) states that international students often have trouble creating search phrases and notes that Chinese students in particular have difficulties because the Chinese language does not have plural and connecting words (p. 163), elements that are often necessary for constructing a successful search in research databases. Varga-Atkins and Ashcroft (2004) note that Boolean searching is an area of difficulty for both native English-speaking and international students but especially difficult for this latter group (p. 49). Morrissey and Given's (2006) found Chinese graduate participants in their study "did not use Boolean operators, or understand how they work" (p. 232). Bahavar, Hanel, Howell \& Xiao (2011) note that finding synonyms and related terms is another challenge for international students in that they have vocabulary limitations (p. 221), which is another linguistic challenge that many non-native English-speaking students confront.

\section{Cultural differences}

Another major reason for challenges faced by international students is due to cultural differences. Cultural differences have implications with regard to international students' attitudes and practices in relation to proper attribution of sources and seeking out help from librarians. As Amsberry (2009) notes, different cultural ideas about textual ownership, for example, "copying [as] a form of respect for an author," may result in students from nonWestern cultures unintentionally committing plagiarism. Cultural differences may also inhibit them from making use of library services and resources. Both Liu and Winn (2009) and Morrissey and Given (2006) mention the cultural idea of "not bothering others" that may prevent international students from seeking help from librarians. Jiao and Onwuegbuzie state that "Compared to native English speaking students, non-native English speaking students tend to have higher library anxiety and emotional discomfort in communicating with librarians and using libraries" (as cited in Ishimura \& Bartlett, 2014, p. 314). Trew (2006) concurs that international students find it more difficult than native speakers when asking for library assistance $(p$. 156). However, despite their initial reluctance due to the difficulty of using English as a second language and cultural differences, Liao, Finn, and Lu's (2007) study reports that international students are far more interested in contacting librarians for help (if they are encouraged to do so) and they more highly value the library as a part of their information-seeking process than their American counterparts (p. 21). In general, cultural differences have impacts on international students' challenges with correctly attributing sources and seeking help but studies show that they gladly make use of the library's assistance if encouraged.

\section{Differing previous learning and research experiences}

Not only do international students face challenges due to linguistic and cultural differences, their previous learning and research experiences also contribute to difficulties they face in western academic learning environments. Liestman (1992) and Fawley (2011) state that international students are accustomed to rote learning rather than independent research. Fawley (2011) elaborates by stating that "International students come from a variety of different educational systems that may place value on attributes such as memorization and group work that are at odds with critical thinking and independent work expected at their host schools" (p. 161). Previous literature indicates that the concept of research is unusual for many international students who may not have previously engaged in this type of activity (Trew, 2006; Morrissey \& Given, 2006). As Ishimura and Bartlett (2014) state, "the academic practice that many [international] students are familiar with [is] very structured and does not allow for independent research (which is often required in the North American educational setting)" (p. 313). Different learning and research experiences may render it difficult for international students to know what is expected in a western academic context. 


\section{Awareness of library services}

Although many researchers emphasize language difficulties as the primary challenge for international students, Liao et al. (2007) state that linguistic differences are less of an encumbrance in the use of library resources by international students than they were in the past. Instead, they claim that a lack of awareness of library, and particularly reference, services is the main obstacle in their use by international students (p. 23). Several authors address international students' lack of awareness of available library services to support their research needs. Liao et al.'s (2007) study shows that many more international respondents felt new to library services such as interlibrary loans, online database searching, in-person consultations with a librarian, and library instruction sessions, compared with the responses from American students in their survey, and surmise that these differences may be due to the lack of such services in international students' home countries (p. 15). Yi (2007) identifies that many international students have intense and frequent needs to improve their library skills and, as a result, are underutilizing the academic library and its services (p. 669). Morrissey and Given (2006) mention the lack of understanding that many international students have about the role of librarians; they note that participants in their study were surprised when informed that librarians could help with information-related activities such as using a library database ( $p$. 228). Datig (2014) concurs that there is a lack of understanding among international students about the role of librarians, stating that "Students do not have a full sense of what we do...students need to know more about librarians' research expertise, subject specialities, technological experience, and contributions to academic knowledge (pp. 355-356). Research suggests that international students lack awareness of many important library services such as interlibrary loan, individual librarian assistance using library databases, and library workshops.

The previous literature suggests many reasons that international students are unaware of the services available through the library, including lack of such services in their home countries. As Trew (2006) notes, "Many foreign libraries serve simply as study halls" and as a result, students are often unaware "of services such as database searching, inter-library loan and term paper consultation [as they] do not exist in their home libraries" (pp. 149-154). Hughes (2010) identifies three factors contributing to international students' lack of awareness: "previously limited information needs, the prevailing pedagogical approaches in their home country, and the differing nature of libraries in their home country and [the host country]" (p. 80). As Liao et al. (2007) note, "Narrow concepts of the nature of library services and functions formed in their own countries [create a] barrier for international students. Many foreign libraries [do] not have the benefit of open stacks and trained librarians." Given previous experiences in their home countries, it is not surprising that some international students may not be aware of the types of services offered by a North American academic library.

Many difficulties related to information literacy have been explored in the previous literature on international students. However, as Liao et al. (2007) observe, most existing literature on international students and academic libraries focuses on the role of the library and its services, with very little literature on the information needs, information-seeking behaviors, and library experiences of international students (pp. 6-7). The current study focuses on this second category - information and research-related needs and experiences of international students and fits into this small but growing area of research. The authors of the current study examine key areas of the research and writing process including selecting a topic, building search strategies, and evaluating, synthesizing and presenting information. The study is unique in that it recruits native Chinese-speaking and native English-speaking students from the same discipline taking the same course who must complete the same assignment. As such, it 
provides interesting insight into how the specific challenges faced by native Chinese-speaking undergraduate engineering students are the same or different from their native Englishspeaking peers, and adds to the little existing literature comparing international and native English-speaking students (Liao et al., 2007; Ishimura \& Bartlett, 2013; Varga-Atkins \& Ashcroft, 2004). Much of the previous literature on international students focuses primarily or exclusively on graduate students (Chen \& Brown, 2012; Liao et al., 2007; Duff, Rogers \& Harris, 2006; Sato \& Hodge, 2009; Ramachandran, 2014; Chen \& Van Ullen, 2011; Han, 2012; Liu \& Winn, 2009; Morrissey \& Given, 2006). However, research suggests that international students' use of library resources and services varies significantly by level of education and lower level undergraduates in particular use the library less than graduate students (Yi, 2007, p. 671). The current study specifically investigates the challenges of undergraduate Chinese students. In addition, the current study builds on the limited number of papers focusing on information literacy needs among engineering students (Chen \& Yao, 2011; Ramanchandran, 2014; Duff et al., 2006; Liu \& Winn, 2009).

\section{Methods}

\section{Participants}

In fall 2013, after ethics approval for the study (certificate \#: 137-0813) and support from the CCOM 206 instructors were obtained, the researchers recruited participants from approximately 350 students enrolled in this course by collaborating with course instructors from each section of the course who allowed the researchers to explain the study and ask for student participation. While students were not provided with any financial incentive, they were encouraged by both librarians and course instructors to participate. The recruitment letter emphasized that participating in the study would provide them with an opportunity to reflect on their research experience and identify existing challenges and difficulties which would significantly benefit their future research, and would help future students. Students were eligible to participate if they were either: (1) A native Chinese-speaking student who had received his or her education in Mainland China, Hong Kong or Taiwan and received eight years or less of his or her education in English in North America, or (2) A native English-speaking student who had received more than half of his or her education in North America. A total of 17 students, eight native Chinesespeaking and nine native English-speaking, participated in the study (see further details about participants in Appendix A). All students were in the first or second year of their engineering programs. No participants had just arrived from a Chinese-speaking environment. All native Chinese-speaking participants in this study had been in Canada or other English-speaking countries for two or more years. Half of them had been in English-speaking environments for two to three years while the other half had been in such an environment for five or more years. None of the participants in either group had attended library instruction sessions at McGill University but most participants in each group had received library instruction in high school or CEGEP (college system requiring completion by Quebec students before entering university). All participants reported having written a research paper in either high school or college.

\section{Data collection and analysis}

The study utilized the Seidman model (1998) to gather data and a grounded theory approach to analyze it. Seidman's (1998) "best interview practice" model is characterized by three interviews allowing participants to reflect on their experience at more than one point and thus enabling researchers to gain a fuller understanding of participants' experiences. Different from this three-interview approach, the current study replaced the second face-to-face interview with 
an online survey, which allowed participants to reflect on their research and writing experience at a convenient time. The modified interview practice consisted of a first interview to familiarize the participants with the study's objectives and obtain their consent, an online survey (used in place of an interview) to identify participants' experiences, and a second semi-structured interview to examine students' challenges in more detail. After they had completed their research paper, participants completed the online survey questionnaire, which consisted of 50 questions on challenges in the research and writing process. The structure of the questionnaire was based on The SCONUL Seven Pillars of Information Literacy: A Research Lens for Higher Education (2011), which are defined as follows:

1. Identify: Able to identify a need for information to address the research question.

2. Scope: Can assess current knowledge and identify gaps.

3. Plan: Can construct strategies for locating information and data.

4. Gather: Can locate and access the information and data they need.

5. Evaluate: Can review the research process and compare and evaluate information and data.

6. Manage: Can organise information professionally and ethically.

7. Present: Can apply the knowledge gained: presenting the results of their research, synthesising new and old information and data to create new knowledge, and disseminating it in a variety of ways. (pp. 5-11)

The survey questions were organized using these categories and followed their sequence, starting with identifying an information need through to presenting research results. The survey was not anonymous; the researchers used the participants' answers to guide the second semistructured interviews.

In the in-depth interview, researchers asked participants to provide further details and explanations about the challenges reported in their survey responses. Like the survey questionnaire, the structure of the interview questions followed the SCONUL format with questions on each of the steps of the research and writing process. For example, in the section on planning their search strategies, researchers asked participants to explain any challenges they faced in forming their search strategies (see Appendix B for sample interview questions). If, in the survey, a participant had responded that he or she found a particular aspect of forming their strategy to be difficult, such as finding synonyms for their search terms, the researchers would ask him or her to explain in further detail. The researchers aimed to reduce interobserver bias by forming the interview questions together. The interviews were conducted by one of the two researchers, each lasting from 35 to 70 minutes and being audio-recorded. The researchers also took brief notes during the interviews.

Native Chinese-speaking participants were given the option to conduct the interviews in either English or Chinese in the hope that native Chinese-speaking participants would have greater ease expressing their challenges in their mother tongue and thereby improve the reliability of the findings. Among the eight native Chinese-speaking participants, five chose to do their interviews in Chinese. The researchers then transcribed the recorded interviews after reading through their interview notes and listening to the recordings several times. This aimed to reduce intra-observer bias and again improve the reliability of the findings. The native Chinesespeaking researcher translated her transcriptions into English. To minimize inter-observer bias, the researchers also randomly transcribed recordings from each other's interviews and compared the transcriptions together to ensure that both researchers were transcribing in a consistent manner. The researchers then coded the transcriptions and generated themes of the 
challenges together after reading through all the transcriptions many times. This also aimed to further reduce inter-observer bias.

\section{Findings and Discussion}

Since the results from the survey data were reported in an earlier publication (Zhao \& Mawhinney, 2014), the current paper reports on the qualitative data gathered from the in-depth interviews with each study participant. The following section documents the challenges that native Chinese-speaking participants faced compared to native English-speaking students when writing a research paper. The similarities and differences between these two groups fall into various aspects of the research process including searching, evaluating, reading, writing, and citing. Participants' comments are presented in the tables according to theme.

Some areas of the research process in the SCONUL model were examined but are not discussed in the findings. They consist of identifying a research topic (Identify), selecting databases and building search strategies (Plan), and using citation software (Manage). These areas presented fewer difficulties among native Chinese-speaking participants and there were no identifiable differences between the two groups. It is believed that the library instruction on these topics provided to the students in the class had a positive effect. Although it was not the goal of the study to investigate differences in information behaviors between the two participant groups, since participants shared many details about their processes and behaviors, the researchers report these findings when they relate to the participants' challenges. Participants' comments are provided in the tables below where their individual participant codes are included. Further details about individual participants are available in Appendix A.

\subsection{Searching for information}

In the current study, researchers asked students about challenges related to searching for information. Unlike previous literature that found that international students had difficulty with searching due to linguistic challenges, this study did not find that students in either group had major difficulties with searching. Students in the current study were recruited from a course where hands-on information-searching instruction was embedded in the class, and students from both groups found searching to be straightforward, although some encountered difficulties due to the specific topics that they selected. The research requirements for this assignment were limited in that students were only required to reference 6-8 scholarly sources. If the students had not received the in-class information searching instruction and/or if they had more intense information needs, it is likely that more difficulties would have been reported.

\subsubsection{Knowledge and use of resources and services}

\section{Native Chinese-speaking participants}

Native Chinese-speaking participants expressed challenges pertaining to the use of library resources and services, and often resulting from a lack of knowledge. None of the native Chinese-speaking participants reported attending a library orientation session at McGill University. As a result, several native Chinese-speaking participants reported having difficulty understanding the library catalogue and cataloguing records, as well as locating items from the library shelves. Students also had difficulty distinguishing between different types of library resources. For example, one student mixed up the library catalogue with Compendex, an engineering research database. Due to these challenges and also to challenges related to reading (discussed in Section 4.3), many native Chinese-speaking students reported not using 
books. Furthermore, none of the native Chinese-speaking participants reported having asked for help from library staff when they encountered difficulties (see Table 1).

\section{Native English-speaking participants}

In comparison, although no native English-speaking students reported attending a library orientation session at McGill University, they showed stronger confidence in using the library catalogue, books, and other services. Several reported having used books available through the library and explained that books helped to generate a general understanding of a topic. They also tended to seek help when they encountered difficulties (see Table 1).

Table 1. Comments on Knowledge and Use of Resources and Services

\begin{tabular}{|c|c|}
\hline Native Chinese-speaking participants & Native English-speaking participants \\
\hline \multicolumn{2}{|l|}{ General comments on searching } \\
\hline $\begin{array}{l}\text { "The easiest part of completing the paper was } \\
\text { searching for articles... I only spent one hour." } \\
\text { (C03) }\end{array}$ & $\begin{array}{l}\text { "It was easy to create my search strategy." } \\
\text { (E05) }\end{array}$ \\
\hline $\begin{array}{l}\text { "It was straightforward to apply search } \\
\text { techniques." (C07) }\end{array}$ & $\begin{array}{l}\text { "Brainstorming and finding synonyms was really } \\
\text { easy... but actually getting results from that } \\
\text { wasn't that obvious." (E01) }\end{array}$ \\
\hline \multicolumn{2}{|l|}{$\begin{array}{l}\text { "I had no clue at the beginning. I spent two hours } \\
\text { but couldn't focus. So I left it to the day before the } \\
\text { due date which gave me great pressure." (C08) }\end{array}$} \\
\hline \multicolumn{2}{|l|}{ Knowledge and use of library catalogue } \\
\hline $\begin{array}{l}\text { "I didn't use the library catalogue and didn't know } \\
\text { what it had. I understood this word - catalogue, but } \\
\text { was not clear what I could found there and how." } \\
\text { (C04) }\end{array}$ & $\begin{array}{l}\text { "I used the library catalogue to search for some } \\
\text { books and located them on the shelf." (E02) }\end{array}$ \\
\hline $\begin{array}{l}\text { "I didn't really know what the library catalogue } \\
\text { [was]. I mixed it up with Compendex." (C08) }\end{array}$ & $\begin{array}{l}\text { "I used the library catalogue to find if the library } \\
\text { had specific journals devoted to [my topic]. I } \\
\text { browsed the table of contents of five or six print } \\
\text { books to get a general understanding of the topic, } \\
\text { and followed citations in these books to find more } \\
\text { online materials." (E01) }\end{array}$ \\
\hline \multicolumn{2}{|l|}{ Knowledge and use of books } \\
\hline $\begin{array}{l}\text { "For a Materials class, the professor only provided } \\
\text { some readings but didn't provide a textbook. I } \\
\text { didn't know where I could find useful } \\
\text { information to help understand the readings. I } \\
\text { used Wikipedia to learn that whole course." (C08) }\end{array}$ & $\begin{array}{l}\text { "The level of language [in books] was easier to } \\
\text { understand, not so condensed, [and] much more } \\
\text { organized." (E06) }\end{array}$ \\
\hline "It was hard to find books on the shelf." (C06) & "Although I did not cite any books in my paper, I \\
\hline
\end{tabular}


found them helpful in providing general

knowledge on a topic." (E02)

\begin{tabular}{l|l}
\hline Knowledge and use of library services & \\
\hline $\begin{array}{l}\text { "I did not know that I could make a request in the } \\
\text { library catalogue to let the library staff look for the } \\
\text { book for me." (C01) }\end{array}$ & $\begin{array}{l}\text { "I had difficulty finding the full text for one } \\
\text { article but I made use of the chat-with-a-librarian } \\
\text { [virtual reference] service and was able to obtain } \\
\text { the article." (E06) }\end{array}$ \\
\hline
\end{tabular}

\section{Discussion}

The current findings related to knowledge and use of library resources concur with the previous literature that library information resources may be unfamiliar to international students. In particular, native Chinese-speaking participants had difficulty with basic library resources, for example, the library catalogue. Previous research shows that international students use the internet rather than library resources more frequently when starting their searches (Liao et al., 2007) and this may be partly due to their lack of familiarity with library resources (Morrissey \& Given, 2006). Many international students lack awareness of information resources and have difficulty locating research material on their own, rather relying on research databases and specific readings provided by their professors (Morrissey \& Given, 2006; Liu \& Winn, 2009). These findings suggest that international students may benefit from library orientation targeted to them.

\subsubsection{Locating full text}

\section{Native Chinese-speaking participants}

All native Chinese-speaking participants except one reported difficulties of some kind in locating full text of articles (see Table 2). Several expressed confusion and/or discouragement that the web page that they were directed to by the Find Full Text button (the library's link resolver) did not display the full text of the article or asked them for payment. In the interviews, participants also mentioned issues relating to finding full text including that McGill Library often did not have the items they wanted. Some reported giving up rather than seeking help to retrieve the full text. When researchers asked participants about interlibrary loan, many said they did not want to wait to receive items, were not familiar with the service, or found the service to be too complicated. One native Chinese-speaking student reported having had an unsuccessful experience using the interlibrary loan service, which discouraged him from using the service.

\section{Native English-speaking participants}

In comparison, the native English-speaking students were slightly divided in their opinions that finding full text was difficult with some students reporting that they had difficulty finding full text and others reporting that they did not. One participant who had difficulty reported contacting a librarian to seek help and was able to obtain the article he needed. Several native Englishspeaking participants reported giving up or finding something else instead when they could not locate a specific article (see Table 2).

\section{Table 2. Comments on Locating Full Text}




\begin{tabular}{l} 
Native Chinese-speaking participants \\
\hline Locating Full Text \\
\hline "It was really hard to find the full text of articles." \\
(C06)
\end{tabular}
(C06)

Native English-speaking participants

"My biggest challenge in researching and writing the paper was finding the full text of articles, especially for older ones. I would see a reference in Google Scholar but not be able to obtain the full text." (E01)

"Sometimes it was difficult finding full text... Most of the time, I would look before I downloaded the abstract whether the full text was

available. Sometimes if I could see a topic that was really close to what I wanted, I would download it anyway and then I would try my best to search for it." (C07)

"I had a lot of trouble obtaining full text... The Find Full Text button usually didn't work and would point to old print volumes of a journal rather than what I needed... I tried interlibrary loan but got discouraged by the form. I would have liked to have the form to be automatically filled out." (E09)

"Locating full text articles was most challenging due to my topic... Most databases didn't provide the full text. I tried googling the full text, even using Chinese titles, but the Chinese sites that provided the full text always asked for a payment." (C04)

"Some results in Compendex produced a page containing links to other places. One of them asked for payment, which was confusing... I only used the articles that I could find either in Compendex or Google Scholar." (C05)

"[Finding full text] was a problem. I was often asked to pay, which was kind of annoying but I was not at a loss because there was enough other relevant information available." (E05)

"I was able to locate the full text of articles without any problems... I was lucky... I know some of my friends had difficulty through finding full text for some of their research. I remember I tried to help my friend find the full text and we had trouble with that. But in my case, the articles I needed did have the full text available." (E04)

"I had trouble getting the full text of journal articles... The links didn't work." (C02)

"Finding full text was straightforward... I had difficulty finding the full text for one article but I made use of the chat-with-a-librarian [virtual reference] service and was able to obtain the article." (E06)

"For my assignment, I gave up [trying to find] many articles... I hope full text access can be improved." (C01)

"I relied on EndNote to find full text. This was because I didn't have time to search for full text manually. I actually was very disappointed after clicking the full text button and receiving error messages. After I reinstalled EndNote, the Find Full Text function started to work. Although nearly half of the full text that I found was not available in Compendex, I really liked that EndNote retrieved full text. I believe this saved me time." (C08)

"I made a request from ILL [interlibrary loan], which I heard about from the library early on in the research 


\begin{tabular}{|c|c|}
\hline $\begin{array}{l}\text { process, but I never got a reply. I won't try it } \\
\text { again." (C02) }\end{array}$ & \\
\hline \multicolumn{2}{|l|}{ Giving up } \\
\hline $\begin{array}{l}\text { "I gave up on [the articles I couldn't find] and only } \\
\text { looked at results that had full text." (CO4) }\end{array}$ & $\begin{array}{l}\text { "I found most of the full text by clicking on the } \\
\text { Find Full Text button. I searched in Google } \\
\text { Scholar for those that did not have their full text } \\
\text { available through the Find Full Text button, but } \\
\text { didn't find all. I gave up on those few ones } \\
\text { since I found a lot of others that were really } \\
\text { relevant, although I knew that I could ask for } \\
\text { those at the library (ILL)." (E02) }\end{array}$ \\
\hline $\begin{array}{l}\text { "I gave up on [articles] that I couldn't find in full text." } \\
\text { (C05) }\end{array}$ & $\begin{array}{l}\text { "[When I couldn't find a specific article], I found } \\
\text { something else because I was under time } \\
\text { constraints." (E09) }\end{array}$ \\
\hline
\end{tabular}

\section{Discussion}

Problems with locating full text were prominent in the current study for both participant groups. No previous literature mentions international students' difficulties in locating full text. Although this is a very specific type of challenge and may be context-specific, given that most academic libraries use link resolvers, it is up to librarians to consider if step-by-step instructions explaining the Find Full Text options should be provided. The study suggests that the information on McGill Library's link resolver page was not self-explanatory enough and both participant groups need further instruction in this area.

\subsection{Evaluating sources}

\section{Native Chinese-speaking participants}

Many native Chinese-speaking participants reported having difficulty evaluating their sources, for example, determining whether or not a source was relevant to their topic and reliable. They determined the relevance of articles based on the abstract provided in a research database such as Compendex, as well as the introduction and conclusion provided in the full text. However, due to challenges related to their relatively slower reading speed in English, some native Chinese-speaking students reported that they often had problems quickly determining if an article was relevant. Many native Chinese-speaking students evaluated the reliability of an article based on if it was from a research database like Compendex or whether the journal title sounded academic. When the question -"what is a peer-reviewed article?"- was asked in the interviews, a number of native Chinese-speaking students reported that they did not fully understand the concept of peer review, although it was mentioned in the assignment description. However, a number of native Chinese-speaking students did some detective work to check facts and references that were mentioned in articles. Another criterion that many native Chinese-speaking students in the study mentioned was that they preferred to use recent articles in their papers. Only one participant reported having thought about author's bias while reading literature (see Table 3 ).

\section{Native English-speaking participants}


In comparison, native English-speaking participants in this study showed more capabilities in evaluating information and sources. Regarding determining the relevance of information, most native English-speaking students found that although new terminology created difficulties in understanding articles, they were able to determine whether or not the articles were relevant to their topic. Many native English-speaking students also based their decisions about the relevance and reliability of information on the content of the article itself, rather than from which database it was found. Most participants in this group mentioned having paid attention to authors' bias while reading literature. They actively sought out the statement of conflict of interest in articles and noticed that sometimes it did not exist in a paper. They checked the author's credentials when they found a key author on a topic, argued with the conclusions that an author made, and questioned if evidence was enough to prove the author's arguments.

Table 3. Comments on Evaluating Sources

\begin{tabular}{|c|c|}
\hline Native Chinese-speaking participants & Native English-speaking participants \\
\hline \multicolumn{2}{|l|}{ Relevance } \\
\hline $\begin{array}{l}\text { "[Having had] difficulty understanding articles } \\
\text { made it hard to know if they were relevant; even } \\
\text { after reading the abstract, [I] didn't always } \\
\text { understand the data, methods, terminology included } \\
\text { in a paper. [I] went to [the] conclusion to get the useful } \\
\text { bits and mostly only used the conclusion to get } \\
\text { findings." (CO7) }\end{array}$ & $\begin{array}{l}\text { "I didn't have problems determining } \\
\text { relevance of information that I found or } \\
\text { knowing if information was credible." (E06) }\end{array}$ \\
\hline \multirow[t]{2}{*}{$\begin{array}{l}\text { "Mostly I determined the relevance by the abstract. } \\
\text { If I found the abstract [was] not relevant, I skipped that } \\
\text { article." (C06) }\end{array}$} & $\begin{array}{l}\text { "I could tell from titles, abstracts, and } \\
\text { conclusions if articles would be relevant." } \\
\text { (E04) }\end{array}$ \\
\hline & $\begin{array}{l}\text { "I had some difficulty determining the relevance } \\
\text { of articles. I couldn't always tell from the } \\
\text { abstract so I went to the full article." (E09) }\end{array}$ \\
\hline \multicolumn{2}{|l|}{ Reliability } \\
\hline $\begin{array}{l}\text { "What's peer reviewed? I don't know. I judged quality } \\
\text { of articles based on the journal title: whether it } \\
\text { sounds academic to me." (C03) }\end{array}$ & $\begin{array}{l}\text { "I found one article cited in many articles, so } \\
\text { I retrieved that the full text and determined that it } \\
\text { was written by a credible author." (E02) }\end{array}$ \\
\hline $\begin{array}{l}\text { "I thought articles from Compendex and IEEE } \\
\text { would be peer reviewed...I didn't know how to } \\
\text { evaluate [if a source was peer reviewed] ...I checked } \\
\text { over my sources again and if it looked scholarly, I } \\
\text { included it." (C06) }\end{array}$ & $\begin{array}{l}\text { "I didn't have difficulty determining if } \\
\text { information was credible because they were } \\
\text { journal articles, most had 5-6 references and the } \\
\text { authors were authoritative." (E05) }\end{array}$ \\
\hline $\begin{array}{l}\text { "I am confident that articles were credible [as I] found } \\
\text { them in Compendex, a reliable source." (C07) }\end{array}$ & $\begin{array}{l}\text { "I was able to tell if it was a credible } \\
\text { [source]. Also seeing advertisements on the } \\
\text { website, you could see how professional it was." } \\
\text { (E04) }\end{array}$ \\
\hline $\begin{array}{l}\text { "Information from journal articles is more specific and } \\
\text { relevant to the topic and it is reliable as I can check }\end{array}$ & $\begin{array}{l}\text { "I liked to look at where the article comes } \\
\text { from. Some of the ones that I found were from }\end{array}$ \\
\hline
\end{tabular}




\begin{tabular}{l|l}
\hline $\begin{array}{l}\text { the methodology and their references...Actually } \\
\text { among the six papers that I cited in this paper, five of } \\
\text { them are related either having each other as co- } \\
\begin{array}{l}\text { authors, or cited their papers in the bibliography." } \\
\text { (C04) }\end{array}\end{array}$ & $\begin{array}{l}\text { either government agencies or research } \\
\text { councils...to me, that makes something } \\
\text { credible...If it was peer reviewed, someone } \\
\text { did that work for me... I thought about it but [it } \\
\text { was] hard to check [author's bias]...[I noted] no } \\
\text { obvious bias or conflict of interest in what I } \\
\text { read." (E09) }\end{array}$ \\
$\begin{array}{l}\text { "I selected articles with a preference for recent } \\
\text { articles. I never considered the bias of authors." } \\
\text { (C01) }\end{array}$ & $\begin{array}{l}\text { "I noticed there was bias in some articles. I } \\
\text { thought they really had to prove their points." } \\
\text { (E07) }\end{array}$ \\
\hline $\begin{array}{l}\text { "I cited many articles published in the 1990s. I thought } \\
\text { they were not recent, so I used IEEE style which } \\
\text { doesn't require including dates in the text...Due to the } \\
\text { time limit, I didn't think about bias from authors." (C08) }\end{array}$ & $\begin{array}{l}\text { "I recognized authors' bias, mostly aware of } \\
\text { this in audio recordings of interviews from the } \\
\text { spokesperson of the project talking to the public. } \\
\text { I recognized that the details she was divulging } \\
\text { were only of a certain nature...some information, } \\
\text { she didn't provide, really only the details that the } \\
\text { public would find important." (E06) }\end{array}$ \\
\hline & $\begin{array}{l}\text { "A few of the conference papers seemed like } \\
\text { people were trying to sell their ideas. They } \\
\text { didn't always consider limitations of } \\
\text { technologies they suggested." (E01) }\end{array}$ \\
\hline
\end{tabular}

\section{Discussion}

In many cases, native Chinese-speaking participants were not familiar with the concept of peer review and tended to judge the quality of a source based on where it was found or published rather than the content itself. Previous literature concurs that international students have difficulty evaluating sources. Varga-Atkins and Ashcroft's (2004) study notes although participants from both the native-speaking and international group had trouble evaluating information, international students had greater difficulty determining if a source was relevant to a given topic (pp. 49-50). Sei-Ching (2015) mentions that how to evaluate the quality of information was a major challenge among international students in the study (p. 472). Han (2012) also reports that international students heavily used the internet for their research and had difficulty evaluating the quality of sources they located (p. 5). According to Trew (2006), difficulties related to evaluating sources including distinguishing between format types are compounded for international students due to linguistic challenges. He notes that it is difficult to identify credible sources when the language is unfamiliar (p. 164). The current study echoes the literature that international students have difficulty evaluating sources for relevance of the information to their topic and credibility of the source.

\subsection{Reading}

\section{Native Chinese-speaking participants}

A good number of native Chinese-speaking students in this study reported having been challenged with reading in English, partly due to their slower reading speeds. As a result, native Chinese-speaking students reported that they had problems reading structured and lengthy journal articles. Although using books was not required in this assignment, many native Chinese-speaking participants expressed concerns about using books because of the time it 
would take to read them and the fear that they would not finish them before the assignment was due. Another reason that they found reading to be challenging was due to terminology and new words included in the journal articles that they selected. Although they could figure out some of the vocabulary based on the context or by looking it up in a dictionary, doing so significantly slowed down their reading pace. As a result, several native Chinese-speaking students only read abstracts and conclusions and skipped the main body of articles. Some expressed their preferences for web sources rather than scholarly articles because the information provided on web pages was simpler and easier to understand. Many native Chinese-speaking students relied on their memories for recording ideas while reading, instead of taking notes. This, in fact, delayed the progression of their papers, as missing notes later on translated into difficulties synthesizing information to build their arguments, as well as citing correctly (see Table 4).

\section{Native English-speaking participants}

In comparison, native English-speaking students did not report having difficulty with reading. They showed confidence in their reading and comprehension abilities even when articles contained scientific jargon with which they were unfamiliar. One native English-speaking student employed techniques such as searching the internet to look up new terminology. Many native English-speaking students took notes to assist with the reading process, which helped them to organize their ideas and integrate information from their readings into the papers later on (see Table 4).

\section{Table 4. Comments on Reading}

\begin{tabular}{|c|c|}
\hline Native Chinese-speaking participants & Native English-speaking participants \\
\hline \multicolumn{2}{|l|}{ Reading books and articles } \\
\hline $\begin{array}{l}\text { "Books are much longer than articles. I was worried } \\
\text { that I had no time to finish reading books for my } \\
\text { paper...I could figure out the meaning of many } \\
\text { words from the context, but I still had problems } \\
\text { with my reading speed...I had a difficult time } \\
\text { with jargon, but generally I could figure it out based } \\
\text { on the context or by looking it up in the dictionary." } \\
\text { (C05) }\end{array}$ & $\begin{array}{l}\text { "I never had problems with my } \\
\text { comprehension. Reading is easy for me. But } \\
\text { there were words that I didn't understand. So I } \\
\text { used Google to search for those words." (E03) }\end{array}$ \\
\hline \multicolumn{2}{|l|}{ "It is time consuming to read books." (C07) } \\
\hline \multicolumn{2}{|l|}{$\begin{array}{l}\text { "I spent a lot of time reading and I struggled with } \\
\text { it. The articles were often very long and discussed } \\
\text { one point in several places...Because English is my } \\
\text { second language, I lost patience while reading. I } \\
\text { could easily read ten pages in Chinese, but lengthy } \\
\text { readings in English were very difficult... I skipped } \\
\text { many terms that I didn't understand as the teacher } \\
\text { had advised." (C03) }\end{array}$} \\
\hline $\begin{array}{l}\text { "I had a lot of trouble reading and understanding } \\
\text { journal literature, the level [of language], the } \\
\text { technical issues, I could not understand what they } \\
\text { were trying to say. In the end, I went to government } \\
\text { websites [pdfs from Natural Resources Canada, }\end{array}$ & \\
\hline
\end{tabular}




\begin{tabular}{|c|c|}
\hline $\begin{array}{l}\text { long informational pamphlets]. They were easier to } \\
\text { understand than journal literature." (C02) }\end{array}$ & \\
\hline $\begin{array}{l}\text { "After reading a relevant abstract in EndNote three } \\
\text { times, I skipped to the conclusion part to see if there } \\
\text { were any ideas that I could cite. Often the } \\
\text { conclusions had jargon which I didn't understand } \\
\text { at all...I was puzzled with terminology, so I read } \\
\text { Wikipedia articles several times in order to } \\
\text { understand...Sometimes I don't have the } \\
\text { corresponding Chinese words in my knowledge } \\
\text { base, so even if I searched in Chinese, I still couldn't } \\
\text { understand the meaning...I often use English } \\
\text { dictionaries." (C08) }\end{array}$ & \\
\hline $\begin{array}{l}\text { "I used internet sources like blogs, government } \\
\text { sites...these sources are more approachable, } \\
\text { simplified, written for a wider audience, not as in- } \\
\text { depth as scholarly sources...It's like reading an } \\
\text { abstract but simpler." (C06) }\end{array}$ & \\
\hline \multicolumn{2}{|l|}{ Note-taking } \\
\hline $\begin{array}{l}\text { "I didn't keep notes of the ideas from my } \\
\text { readings. I only tried to remember them." (C05) }\end{array}$ & $\begin{array}{l}\text { "I took notes as I read and then wrote something } \\
\text { relevant." (E02) }\end{array}$ \\
\hline $\begin{array}{l}\text { "It was hard to keep track of notes taken from } \\
\text { readings. After I read articles for a few times, I } \\
\text { started writing. Then I recognized that I couldn't } \\
\text { recall from which article I got the idea. Some } \\
\text { knowledge was even out of the articles, and I } \\
\text { couldn't remember where I read it." (C03) }\end{array}$ & $\begin{array}{l}\text { "I highlighted passages I felt I could use later } \\
\text { on." (E09) }\end{array}$ \\
\hline
\end{tabular}

\section{Discussion}

Since English language proficiency is a difficulty for many international students, reading posed unique challenges for native Chinese-speaking students in this study. The findings confirm those from the previous literature on international students from Asia, showing that they read English at much slower speeds (Trew, 2006, p. 152) and have much lower comprehension compared to native English-speaking students (Morrissey \& Given, 2006, p. 223). In addition, previous literature concurs with the findings from the current study that note-taking is difficult for international students due to both linguistic challenges and lack of skills. Dunkel and Davy's (1989) study on note-taking among international students in the classroom observes that they find it challenging due to linguistic difficulties (p. 47).

\subsection{Writing}

\section{Native Chinese-speaking participants}

All the native Chinese-speaking participants in this study reported finding it particularly difficult to write their research papers. Specific challenges consisted of linguistic difficulties, writing persuasively, synthesizing information, and developing outlines. First, the writing challenges 
were no doubt related to their lower English proficiency. As a result, they had difficulty varying sentence structures and word choices when writing in English. Some native Chinese-speaking participants reported that they had problems with grammar (for example, using prepositions properly). Secondly, many native Chinese-speaking students reported finding it challenging to synthesize information that they found in the literature to support their arguments. Thirdly, making their arguments persuasive was another writing-related challenge. As their assignment required, students needed to not only present information on a topic but also use evidence to argue for the solutions that they chose. Many students reported not having written in this style before (past papers having been more informative in nature) and finding it difficult to make their papers persuasive. Finally, making an outline for the paper was reported as another challenge by native Chinese-speaking participants. Several of them mentioned having received instruction from their CCOM 206 instructors on making an outline and found it was helpful for structuring their papers. Some native Chinese-speaking participants reported that it was useful to have their native English-speaking friends proofread their drafts. Several others also found it helpful to have the peer-review activity in the class where they received feedback from their peers on their drafts (see Table 5). These methods indicate a potential way to help non-native English-speaking students through a peer support approach.

\section{Native English-speaking participants}

In comparison, native English-speaking participants reported that writing was relatively easy. None of the English-speaking participants reported having linguistic problems, such as difficulties with grammar, word choice, or sentence structure as native Chinese-speaking students had. However, similar to native Chinese-speaking students, they had difficulties with synthesizing information, writing persuasively, and creating outlines. It is understandable that students in both groups found these elements of writing to be challenging since most of the students were in their first or second year of university and had limited previous experience in writing research papers. Many native English-speaking students found it helpful to read sample papers, which provided them with useful information on structuring their papers (see Table 5). This illustrates that a peer support approach, where students have access to sample papers from other students and/or work with their peers to help each other with writing, would be valuable not only to non-native English-speaking students but also to all students in the class.

\section{Table 5. Comments on Writing}

\begin{tabular}{|c|c|}
\hline Native Chinese-speaking participants & Native English-speaking participants \\
\hline \multicolumn{2}{|l|}{ General comments on writing } \\
\hline $\begin{array}{l}\text { "Writing was the most challenging part of the process. I } \\
\text { especially felt challenged in expressing ideas in English. } \\
\text { Something that could be easily spoken out in Chinese is } \\
\text { much harder to form in English...This class included an in- } \\
\text { class peer-review process, which allowed students to read } \\
\text { each other' drafts. I thought it was useful." (C05) }\end{array}$ & $\begin{array}{l}\text { "The writing part was relatively easy." } \\
\text { (E01) }\end{array}$ \\
\hline $\begin{array}{l}\text { "I was worried about writing such a long paper but it } \\
\text { actually ended up being longer than I expected." (CO2) }\end{array}$ & $\begin{array}{l}\text { "Writing was the easiest part...It went } \\
\text { smoothly." (E04) }\end{array}$ \\
\hline $\begin{array}{l}\text { "I repeated my words and sentences all the time, which I } \\
\text { shouldn't do." (CO3) }\end{array}$ & "The writing was pretty quick." (E02) \\
\hline
\end{tabular}




\section{Linguistic difficulties \\ "My two CBC [Canadian-born Chinese] friends helped correct the grammar mistakes in my paper, but my instructor still pointed out many sentence structure problems...I had difficulty creating a title for the paper. That is, using the most effective words to summarize the content. I felt I didn't have the ability to make an attractive and concise title in English." (C01) \\ "I had problems with prepositions, especially with 'in' and 'for'. I...gained a feeling of the difference between 'to' and 'for', but it's still not very clear." (C08)}

"I had problems in using [the English] language precisely. Sometimes I had to use a dictionary to compare the usage of different words in order to select the one that I really needed." (C05)

\section{Synthesizing information \\ "Compared to papers that I wrote in high school, I had to collect points from other papers and cite them in my paper, which was very different and challenging." (C03)}

"[The] biggest challenge was that there are all kinds of ideas floating around; you need to pick out the key ones you want to use... How can you make that example or statistic support your argument and how do you make it flow well? That's the biggest challenge." (C07)

"For this paper, the professor asked us to provide more written reason[s] [with a] purpose... but my previous paper was more informative... When I try to be persuasive, I have to find lots of information and put it together and integrate [it] into my outline instead of the outline of the author...[l had] a lot of trouble reading and understanding journal literature. I could not incorporate [the readings] into my paper...they were too specific." (C02)
"Some readings were very advanced and complicated. I wanted it to flow well...It was hard for me to incorporate these facts into my paper." (E04)

"I found it difficult to incorporate ideas from readings into my paper, especially for journal articles...I wrote down everything I knew in unorganized paragraphs and then structured the information after." (E06)

"I had a pretty good experience incorporating ideas from readings into the paper, [although it was] kind of difficult...to use facts in the appropriate sections of my paper." (E05)

“Lots of papers don't focus on using theory to solve a problem so it's kind of hard. You have to extrapolate a lot of stuff that you don't necessarily have the knowledge or the required background to be able to do." (E08) 


\begin{tabular}{|c|c|}
\hline Persuasive writing & \\
\hline $\begin{array}{l}\text { "The persuasive part was difficult. When communicating } \\
\text { ideas clearly to the audience, [one] needs to make strong } \\
\text { arguments. I didn't made them strong enough in my first draft } \\
\text { and was asked to make it more convincing by varying some } \\
\text { of the arguments, deleting some of the arguments, and } \\
\text { changing some...for example, adding a new kind of table...to } \\
\text { further prove my point." (C07) }\end{array}$ & $\begin{array}{l}\text { "Making the paper persuasive was } \\
\text { hard for me, as I didn't know much about } \\
\text { the topic... Defining the audience was } \\
\text { difficult, [whether to have] a general } \\
\text { audience or a more specific one..." (E02) }\end{array}$ \\
\hline \multicolumn{2}{|l|}{ Developing outlines } \\
\hline $\begin{array}{l}\text { "... the hardest part was mapping out how to structure } \\
\text { the paper and how much depth to cover in each part." (C06) }\end{array}$ & $\begin{array}{l}\text { "The hardest part [was that] the } \\
\text { outlines and main ideas of other papers } \\
\text { didn't work in my own." (E09) }\end{array}$ \\
\hline $\begin{array}{l}\text { "Without the outline, I wouldn't have been able to finish } \\
\text { this paper. My outline evolved as my research went on. I } \\
\text { updated it along the way." (C08) }\end{array}$ & $\begin{array}{l}\text { "The skeleton part was hard. What the } \\
\text { paper would look like was tricky." (E02) }\end{array}$ \\
\hline
\end{tabular}

\section{Discussion}

Writing was one of the most prominent challenges for native Chinese-speaking participants, which echoes findings from the previous literature. Challenges are not only due to the linguistic limitations of non-native English-speaking students but also to their cultural and educational differences (Woodward-Kron, 2007, pp. 253-254). For example, in the current study, many native Chinese-speaking participants reported difficulties with persuasive writing and synthesizing information, which are largely due to a lack of previous experience using these techniques. These were also challenges for native English-speaking participants but to a lesser extent. Many students in both groups expressed the desire for further guidance on writing techniques. Previous literature also shows that international students from Asia have difficulties with writing, especially in the early years of their programs (Sato \& Hodge, 2009, p.141), which concurs with the current findings in that all the participants in this study were in their first or second years. There is a need for providing further writing support to non-native Englishspeaking students, especially in the early years of their programs.

\subsection{Citing}

\section{Native Chinese-speaking participants}

All the native Chinese-speaking participants in this study reported difficulties in determining when and how to cite to some degree (see Table 6). Knowing when to cite is associated with students' understanding of common knowledge and attitude towards attributing credit to the original author, whereas knowing how to cite relates to the techniques used for citing. Knowing how to cite was a major difficulty reported among the native Chinese-speaking participants in this study, although one student also had difficulty knowing when a citation to a source was needed. Students had difficulty dealing with paraphrasing and quoting in particular. Some relied exclusively on either paraphrasing or quoting directly, and several reported difficulties determining when to paraphrase and when to use direct quotes. One of the reasons that native Chinese-speaking students encountered these difficulties is related to their relatively low proficiency using English, as several participants reported that they were unable to paraphrase 
or summarize a statement to reflect the full meaning of the original one. The other reason for difficulties related to citing is due to these students' inexperience with academic writing in English, as several participants reported that there were substantial citing rules and techniques for in-text citing, and graph and table citing that they had not yet grasped.

\section{Native English-speaking participants}

In comparison, native English-speaking participants had fewer difficulties with citing rules and techniques. Many reported that they had gained knowledge of when and how to cite in high school and CEGEP and were comfortable dealing with citing, with the exception of one student who reported difficulties determining whether or not certain information was common knowledge. Instead, native English-speaking students often had more specific technical issues related to citing. For example, two English students reported difficulty with citing the same reference in multiple places in their papers and they solved this problem after consulting their instructors. One reported not knowing how frequently he needed to cite when paraphrasing. Another had difficulty identifying and generating citations for non-standard information sources. Some students expressed the desire to have an online guide to consult for their specific citation questions (see Table 6).

\section{Table 6. Comments on Citing}

\begin{tabular}{|c|c|}
\hline Native Chinese-speaking participants & Native English-speaking participants \\
\hline \multicolumn{2}{|l|}{ Determining when to cite } \\
\hline $\begin{array}{l}\text { "I wrote about many points that I got from my } \\
\text { readings, but I didn't realize that I should cite } \\
\text { them." (C01) }\end{array}$ & $\begin{array}{l}\text { "I wish there was an online guide about what } \\
\text { common knowledge is and when I should } \\
\text { cite. I was not clear about that." (E03) }\end{array}$ \\
\hline \multicolumn{2}{|l|}{ Determining how to cite } \\
\hline $\begin{array}{l}\text { "I am not used to quoting...I thought no more than } \\
\text { six words can be copied directly as it is } \\
\text { plagiarizing. I didn't know how to quote } \\
\text { correctly...I never learnt this in a class." (C08) }\end{array}$ & $\begin{array}{l}\text { "I didn't have difficulty knowing how to } \\
\text { paraphrase and use direct quotes. [I was] } \\
\text { taught in [CEGEP]...What requires an in-text } \\
\text { citation at the end of a sentence, that's what I } \\
\text { wasn't sure about." (E04) }\end{array}$ \\
\hline $\begin{array}{l}\text { "I was not very clear about when to summarize } \\
\text { and when to quote directly. The instructor didn't } \\
\text { like direct quotes longer than four lines. So I mainly } \\
\text { paraphrased... I really like the original quotes in the } \\
\text { text, and I had a difficult time paraphrasing an } \\
\text { idea as well as the original one...The techniques } \\
\text { for citing were not taught in detail in high school } \\
\text { either. Only an example sheet was handed out at } \\
\text { that time...I prefer general instruction of citing in- } \\
\text { class and also individual corrections from the } \\
\text { instructor." (C05) }\end{array}$ & $\begin{array}{l}\text { "I found citing easy...My only problem with citing } \\
\text { was different versions of APA, there was a more } \\
\text { recent version (6th). Some of the formatting was } \\
\text { wrong." (E01) }\end{array}$ \\
\hline $\begin{array}{l}\text { "I thought the in-text citation was easy to deal with, } \\
\text { just the author and date. However, my instructor }\end{array}$ & $\begin{array}{l}\text { "I had trouble identifying parts of a citation } \\
\text { because some sources were non-standard }\end{array}$ \\
\hline
\end{tabular}




\begin{tabular}{l|l}
\hline $\begin{array}{l}\text { gave me a lot of feedback on in-text citations." } \\
\text { (C04) }\end{array}$ & $\begin{array}{l}\text { (e.g. podcasts, personal communication, Google } \\
\text { Earth, etc.)...and for how to cite the same source } \\
\text { multiple times...I asked [my instructor] for } \\
\text { clarification." (E06) }\end{array}$ \\
\hline $\begin{array}{l}\text { "The teacher had problems with my } \\
\text { quotations. The teacher recommended } \\
\text { paraphrasing instead of direct quoting as she } \\
\text { commented 'Good quote! Can you paraphrase?"' } \\
\text { (C03) }\end{array}$ & $\begin{array}{l}\text { "I consulted the instructor after the class on how } \\
\text { to cite the same reference in several places in } \\
\text { a paper." (E07) }\end{array}$ \\
\hline $\begin{array}{l}\text { "It was challenging to cite tables and graphs... } \\
\text { which was not mentioned in the class... I didn't } \\
\text { know where to look for further instruction." (C06) }\end{array}$ & \\
\hline
\end{tabular}

\section{Discussion}

The findings in the current study concur with the previous literature that international students have difficulties knowing when and how to cite. Several native Chinese-speaking students in the current study reported having difficulty understanding why they should cite and therefore did not know when a reference was needed. This is similar to Morrissey and Given (2006)'s findings of Chinese students that "Many participants felt that copyright and attribution were unimportant or were intended to be common-sense guidelines, rather than formal rules or laws" (p. 234). Many studies identify that international students need guidance on attributing sources. For example, Duff et al. (2006) identify referencing techniques as one of the areas where students have the most difficulty (p. 679). Reasons for these difficulties include "limited language abilities, different learning practices, and different ideas about textual ownership" (Ishimura and Bartlett, 2014, p. 314). Trew (2006) and Fawley (2011) add that difficulties related to citing may also arise from cultural differences, specifically the idea that copying is a sign of respect and that it is disrespectful to change an author's words by paraphrasing them. Asian cultures often focus on recitation as a form of learning and there is not as much emphasis on citing sources as in Western culture. The current findings indicate that Chinese students' difficulties with citing appear to be unintentional and largely due to their lack of knowledge and skills. This finding concurs with previous ones such as Fawley (2011) who states that "Most students unintentionally plagiarize, or misuse sources, because of careless or inadequate use of citing and an inability to take adequate notes and paraphrase properly" (p.159). Similarly, Bretag (2007) asserts that there is a connection between language difficulties and plagiarism in that students who are struggling with a second language may inadvertently resort to plagiarism (p.15). In summary, the literature and the current findings show that cultural differences, lack of referencing skills, and linguistic difficulties result in challenges related to citing.

\section{Recommendations}

Based on the prominent challenges among native Chinese-speaking participants that were identified in this study, the following section includes recommendations for future practice related to international students whose mother tongue, cultural backgrounds, learning behaviors, and previous experience of libraries differ from those of the country of study. Most of the problems encountered by native Chinese-speaking participants were related to the second part of the research and writing process, namely, writing, reading, and citing. These skills are not normally ones that librarians focus on during library instruction and, as noted by Fawley (2011), collaboration with other units such as writing centres or international student service centres will 
facilitate international students further developing these skills (p. 161). The recommendations are grouped in response to the primary challenges identified in this study, namely, writing, reading, and citing, as well as searching for and evaluating information.

Writing, reading, and citing

Both native Chinese-speaking and native English-speaking participants reported challenges with persuasive writing, synthesizing information, and building paper outlines. However, these challenges were more prominent among native Chinese-speaking participants. It is recommended that all students have more opportunities to develop these skills by incorporating more research and writing components into the university curriculum. It is also suggested that the university provide increased support for non-native English-speaking students to acquire these skills before graduation.

The ACRL's Framework for Information Literacy for Higher Education marks a shift in thinking from the traditional information literacy standards that came before. Part of the emphasis of the new framework is moving from considering users to be primarily consumers of information to also being creators. For example, the fifth Frame is "Scholarship as conversation" and emphasizes that learners are developing their information literacy abilities when they are "contributors to scholarship rather than only consumers of it" (Association of College \& Research Libraries, 2015). Given this new context and the findings from the current study, researchers recommend that librarians consider taking advantage of this opportunity to expand their roles, focusing not only on teaching students how to search for information but also how to use it, in the form of enhanced instruction on synthesizing information and "contribut[ing] to scholarly conversation at an appropriate level" (Association of College \& Research Libraries, 2015). Such involvement in these aspects of the research and writing process will work best through increased collaboration with other units on campus such as the relevant faculties and departments, writing centres, and international student centres, and could involve the development of a scaffolded academic writing program. Such enhanced services will be of benefit to non-native English-speaking international and native-English speaking students alike.

One way of helping students improve their writing skills would be by developing a practice of providing sample papers to students. Many students in the study reported that it was useful to read sample papers supplied by their instructors. It is recommended that instructors provide students with sample papers, explaining what aspects make a paper strong. In fact, McGill Library is currently partnering with the instructors of CCOM 206 to host the winning paper of the Writing Recognition Award for each semester in the library's institutional repository. Winning papers are those that stand out in terms of the overall quality of writing. These papers can then be consulted by future CCOM 206 as models to follow. This initiative is an example of the Writing Centre, the Faculty of Engineering, and McGill Library collaborating to encourage the development of engineering students' writing skills.

Another way libraries can be involved in encouraging the development of writing skills is by having students write for the library's blog. In recent semesters, McGill librarians have invited students from CCOM 206 to write for the Schulich Library blog, the Turret (https://blogs.library.mcgill.ca/schulich/), and have mentored them as they find their voices as bloggers. This provides another opportunity for students to improve their writing skills.

The current study also shows that native Chinese-speaking participants had difficulties with reading and needed to improve their skills related to gathering information from their readings. 
Several authors explicitly suggest offering reading support to international students. One suggestion is to have a reading club for international students. This practice has been implemented successfully by the library at the University of Technology in Australia. As reported by Byrne (2011), reading clubs help international students adjust to a foreign country by building confidence in their reading skills (p. 208). One specific technique that researchers in the current study noticed that native Chinese-speaking participants lacked was note-taking. As previous literature suggests, international students desire to learn these skills (Dunkel \& Davy, 1989, p. 47). Providing instruction on note-taking would be beneficial to international students as it would enable them not only to read information more efficiently but also to better retain it for the purposes of later synthesizing and citing it.

The current findings suggest that international students need more instruction on citing, including why a citation should be provided, when a citation is required, and how to do so correctly. Developing international students' skills in relation to citing is important to level the playing field with native English-speaking students regarding academic expectations. Many authors concur that there is such a need (Gunnarsson, Kulesza \& Pettersson, 2014; Chen \& Brown, 2012; Fawley, 2011; Chen \& Van Ullen, 2011; Duff et al., 2006; Shao, Scherlen, Johnson, Xu \& Hu, 2013) and several provide examples of workshops and instruction with evidence that they are successful (Chen \& Van Ullen, 2011; Duff et al., 2006). Instruction could facilitate students' acquisition of paraphrasing and summarizing skills as previous literature suggests these skills may be new to international students (Han, 2012, p. 14). Some students in the current study also expressed a need for online guides that provide detailed examples of common knowledge, as well as information on when and how to cite. Providing such guides would be helpful not only for international students but also for students in general.

\section{Searching for and evaluating information}

The current study did not find that native Chinese-speaking students had many difficulties searching for information. The previous literature identifies that this is an area where international students require instruction, including database searching (Yi, 2007, p. 669) and building search strategies (Liao et al., 2007, p. 24; Bahavar et al., 2011, p. 221). The CCOM 206 library instruction sessions cover how to build search strategies using synonyms, Boolean operators, and other features available in research databases. The participants in this study reported that they had very few challenges related to database searching, suggesting that the library instruction was successful. However, two areas related to searching for information that were problematic were using the library catalogue and locating full text.

Many native Chinese-speaking students in this study were not fully aware of library resources and services available to them, and several reported being reluctant to use them. The findings from the first interview indicate that none of them attended McGill Library's orientation sessions. Therefore, simply assuming that students will learn about library basics such as using the library catalogue from attending orientation sessions is not sufficient. It is recommended that the library target international students with workshops covering basic material such as searching the library catalogue and the range of library services offered, including consultations with a librarian, interlibrary loan, scanning services, services for requesting an item from the shelf, suggesting a purchase services, etc. This could be done in multiple formats such as library orientation in students' native languages, video tutorials, and peer-led programs that promote library services among international students in particular. Promotion in collaboration with other units on campus such as international student services would be effective in reaching these students. 
In this study, participants, especially native Chinese-speaking participants, encountered difficulties locating the full text of articles. Although this could be a local issue, it may be widespread and affect students elsewhere. This finding has not been explored in the previous literature and therefore further investigation would be useful to validate it. This study also identified that native Chinese-speaking participants tended to give up when they were not able to locate the full text. Although this behavior did not present major difficulties in this assignment (since students were only required to reference six to eight scholarly sources), it could have an impact for students who need to conduct more comprehensive literature searches as they may miss articles that are important for their research topics. One recommendation is to spend time during existing library instruction sessions or create online instructional material explaining options for item fulfilment. Another recommendation is to incorporate into library instruction critical thinking about the variety of formats where research material is published so that students will better understand what types of resources they are looking for and where to locate them (Seeber, 2015).

Another finding from the current study suggests that native Chinese-speaking students need instruction on evaluating sources according to their reliability and relevance to the research topic. This could be achieved through in-person library instruction or online materials such as a rubric for evaluating sources that would help international students establish the practice of analyzing information sources.

\section{Conclusion}

In summary, this study examined information literacy challenges that entry-level engineering students confront in the research and writing process. Major challenges specific to native Chinese-speaking participants were more pronounced in the second half of this process, including reading and writing in English as well as citing in an academic paper. Lack of knowledge of basic library resources and services and evaluating sources remained challenging for native Chinese-speaking students. This calls for targeted initiatives offered to these students, perhaps through library orientation for non-native English speakers, online guides, or targeted workshops in areas identified as challenges in the current study, such as citing and evaluating information. Both native Chinese-speaking and native English-speaking groups had difficulties with synthesizing information from their readings, creating outlines, writing persuasively, and locating full text of articles. The findings suggest that changes to the librarian's traditional role within information literacy instruction from teaching how to search for and evaluate information to include how to synthesize information and contribute to scholarship could be beneficial to both non-native English-speaking students and native English-speaking students alike but will involve collaborations among different academic units on campus.

The study reports on students from one course at one university and may not be representative of native Chinese-speaking students at other North American universities. All native Chinesespeaking participants in this study had been in an English-speaking environment for two or more years. There were no participants who had just arrived from China. Their research experiences and the challenges they encountered might be less problematic than those who had only recently arrived from China.

The current study identified fewer challenges in areas where the participants had received library instruction, such as choosing a research database, building search strategies, and using citation management software (EndNote). This may be due to instruction having been provided to CCOM 206 students in the two library workshops covering the research process and available information resources. It is hard to imagine what further challenges native Chinese- 
speaking students may have encountered without having had the library workshops. In fact, many international students may not receive any type of library instruction while researching their papers, which could generate additional challenges that were not identified in this study.

Implications for practice

McGill Library is currently developing mechanisms to address the needs identified in the current study. As suggested in the previous literature, there are obstacles to international students becoming aware of library resources and services. One way to overcome these obstacles is by reaching out and supporting international students through peer support. Many Chinese students in the current study reported that having help from their peers in the forms of peer reviewing of papers and sample papers from previous students supplied by their instructors was useful. This suggests a possibility of using peers to enhance student learning, which could be adapted into the library context through programs such as the recently implemented Peer Support Program for International Students at McGill Library, where upper-level international engineering students will be trained to provide help to their international peers in using the library's resources and services. This initiative provides an alternative to traditional services by having not only librarians but also international students reach out to their peers.

\section{Future research}

Future research could examine the challenges that are faced by international students who have more recently arrived to North America since it is likely that their challenges would be greater and different than those identified among students who have already established themselves in their host countries. It could also include examining not only students' perspectives but also those of instructors and/or librarians. The challenges discussed in the current study were only self-identified by students, and research shows that students tend to overrate their information literacy skills (Molteni \& Chan, 2015, p. 6; Kim \& Shumaker, 2015, p. 453). Therefore, gathering input from other stakeholders such as course instructors and/or librarians may give a fuller picture of challenges faced by native Chinese-speaking students in North America. Another possibility would be to examine international students' challenges in courses where no library instruction is provided to see how they differ from those identified in the current study. An additional area of future research could be to examine the impact of targeted information literacy on the competencies of Chinese and other international students. One final area of future research could be to examine differences in information behavior between native Chinese-speaking and native English-speaking students since better understanding these differences has the potential to positively inform future practice.

\section{Acknowledgements}

The researchers wish to sincerely thank the participants in this study who generously provided their time and experience to help improve understanding of their information literacy challenges. They also acknowledge April Colosimo, Giovanna Badia, Dr. Diane Dechief, and Dr. Sue Laver for providing constructive feedback on this paper. A special thank you goes to the instructors of CCOM 206, who helped to recruit participants for this study and collaborate with the library in many ways.

\section{References}

ABET. (2015). Criteria for accrediting engineering programs, 2015-2016. Retrieved from 
www.abet.org/accreditation/accreditation-criteria/criteria-for-accrediting-engineering-programs2015-2016/\#students

Amsberry, D. (2009). Deconstructing plagiarism: International students and textual borrowing practices. The Reference Librarian, 51(1), 31-44. http://dx.doi.org/10.1080/02763870903362183

Association of College \& Research Libraries. (2015). Framework for information literacy for higher education. Retrieved from www.ala.org/acrl/standards/ilframework

Bahavar, S., Hanel, N., Howell, K., \& Xiao, N. (2011). The University of Southern California's campus-wide strategies to reach international students. In P. A. Jackson \& P. Sullivan (Eds.), International students and academic libraries: Initiatives for success (pp. 213-231). Chicago, III.: Association of College and Research Libraries.

Bretag, T. (2007). The emperor's new clothes: Yes, there is a link between English language competence and academic standards. People and Place, 15(1), 13-21.

Byrne, A. (2011). An Integrated approach to supporting international students at the University of Technology, Sydney in Australia. In P. A. Jackson \& P. Sullivan (Eds.), International students and academic libraries: Initiatives for success (pp. 201-211). Chicago, Ill.: Association of College and Research Libraries.

Chen, Y., \& Brown, C. (2012). Ensuring Chinese engineering graduate students' academic success: A study at the University of Oklahoma. Science and Technology Libraries, 31(3), 320341. http://dx.doi.org/10.1080/0194262X.2012.705144

Chen, Y.-H., \& Van Ullen, M. K. (2011). Helping international students succeed academically through research process and plagiarism workshops. College \& Research Libraries, 72(3), 209235. http://dx.doi.org/10.5860/crl-117rl

Datig, I. (2014). What is a library?: International college students' perceptions of libraries. Journal of Academic Librarianship, 40(3-4), 350-356.

http://dx.doi.org/10.1016/j.acalib.2014.05.001

Duff, A. H., Rogers, D. P., \& Harris, M. B. (2006). International engineering students-avoiding plagiarism through understanding the Western academic context of scholarship. European Journal of Engineering Education, 31(6), 673-681.

http://dx.doi.org/10.1080/03043790600911753

Dunkel, P., \& Davy, S. (1989). The heuristic of lecture notetaking: Perceptions of American \& international students regarding the value \& practice of notetaking. English for Specific Purposes, 8(1), 33-50. http://dx.doi.org/10.1016/0889-4906(89)90005-7

Engineers Canada. (2014). 2014 Canadian Engineering Accreditation Board: Accreditation criteria and procedures. Retrieved from www.engineerscanada.ca/sites/default/files/2014_accreditation_criteria_and_procedures_v06.p df

Enrolment Services, McGill University. (2015). Enrolment reports. Retrieved from www.mcgill.ca/es/registration-statistics 
Fawley, N. (2011). Addressing academic integrity: Perspectives from Virginia Commonwealth University in Qatar. In P. A. Jackson \& P. Sullivan (Eds.), International students and academic libraries: Initiatives for success (pp. 151-164). Chicago, III.: Association of College and Research Libraries.

Government of Canada. (2015). International students with a valid permit on December 31st by top 50 countries of citizenship, 2004 to 2013. Retrieved from www.cic.gc.ca/english/resources/statistics/facts2013/temporary/4-2.asp

Gunnarsson, J., Kulesza, W. J., \& Pettersson, A. (2014). Teaching international students how to avoid plagiarism: Librarians and faculty in collaboration. Journal of Academic Librarianship, 40(3-4), 413-417. http://dx.doi.org/10.1016/j.acalib.2014.04.006

Han, J. (2012). The Experiences of Chinese PhD students in Australia: A biographical study. Journal of Information Literacy, 6(1), 3-17. http://dx.doi.org/10.11645/6.1.1603

Hensley, M. K., \& Love, E. (2011). A multifaceted model of outreach and instruction for international students. In P. A. Jackson \& P. Sullivan (Eds.), International students and academic libraries: Initiatives for success (pp. 115-134). Chicago, III.: Association of College and Research Libraries.

Hughes, H. (2010). International students' experiences of university libraries and librarians. Australian Academic \& Research Libraries, 41(2), 77-89.

http://dx.doi.org/10.1080/00048623.2010.10721446

Institute of International Education. (2014). Open doors data: International students: Fields of study. Retrieved from www.iie.org/Research-and-Publications/Open-Doors/Data/InternationalStudents/Fields-of-Study/2012-14

Institute of International Education. (2015). Open doors data: Fast facts. Retrieved from www.iie.org/Research-and-Publications/Open-Doors/Data/Fast-Facts

Ishimura, Y. (2013). Information behavior and Japanese students: How can an understanding of the research process lead to better information literacy? Public Services Quarterly, 9(1), 20-33. http://dx.doi.org/10.1080/15228959.2013.758977

Ishimura, Y., \& Bartlett, J. C. (2013). Uncovering the research process of international students in North America: Are they different from domestic students? Information Research, 18(1).

Ishimura, Y., \& Bartlett, J. C. (2014). Are librarians equipped to teach international students? A Survey of current practices and recommendations for training. Journal of Academic Librarianship, 40(3-4), 313-321. http://dx.doi.org/10.1016/j.acalib.2014.04.009

Kim, S. U., \& Shumaker, D. (2015). Student, librarian, and instructor perceptions of information literacy instruction and skills in a first year experience program: A case study. Journal of Academic Librarianship, 41(4), 449-456. http://dx.doi.org/10.1016/j.acalib.2015.04.005

Liao, Y., Finn, M., \& Lu, J. (2007). Information-seeking behavior of international graduate students vs. American graduate students: A user study at Virginia Tech 2005. College and Research Libraries, 68(1), 5-25. http://dx.doi.org/10.5860/crl.68.1.5 
Liestman, D. (1992). Implementing library instruction for international students. PNLA Quarterly, 56(2), 11-14.

Liu, G., \& Winn, D. (2009). Chinese graduate students and the Canadian academic library: A user study at the University of Windsor. Journal of Academic Librarianship, 35(6), 565-573. http://dx.doi.org/10.1016/j.acalib.2009.08.001

Liu, M., \& Redfern, B. (1997). Information-seeking behavior of multicultural students: A case study at San Jose State University. College \& Research Libraries, 58(4), 348-354. http://dx.doi.org/10.5860/crl.58.4.348

McGill University. (2015). CCOM 206 Communication in engineering (3 credits). Retrieved from www.mcgill.ca/study/2015-2016/courses/ccom-206

Molteni, V. E., \& Chan, E. K. (2015). Student confidence/overconfidence in the research process. Journal of Academic Librarianship, 41(1), 2-8.

http://dx.doi.org/10.1016/j.acalib.2014.11.012

Morrissey, R., \& Given, L. M. (2006). International students and the academic library: A case study. Canadian Journal of Information and Library Science, 30(3-4), 221-239.

Ramachandran, H. (2014, June 10). International students within our borders: Improving information literacy and library services for graduate engineering students. Paper presented at the Special Libraries Association Conference, Vancouver, B.C. Retrieved from www.sla.org/2014-contributed-papers

Sarkodie-Mensah, K. (1998). International students in the U.S.: Trends, cultural adjustments, and solutions for a better experience. Journal of Education for Library and Information Science, 39(3), 214-222. http://dx.doi.org/10.2307/40324159

Sato, T., \& Hodge, S. R. (2009). Asian international doctoral students' experiences at two American universities: Assimilation, accommodation, and resistance. Journal of Diversity in Higher Education, 2(3), 136-148. http://dx.doi.org/10.1037/a0015912

The SCONUL Working Group on Information Literacy. (2011). The SCONUL seven pillars of information literacy: A research lens for higher education. Retrieved from www.sconul.ac.uk/sites/default/files/documents/researchlens.pdf

Seeber, K. P. (2015). Teaching "format as a process" in an era of web-scale discovery. Reference Services Review, 43(1), 19-30. http://dx.doi:10.1108/RSR-07-2014-0023

Sei-Ching, J. S. (2015). Demographic differences in international students' information source uses and everyday information seeking challenges. Journal of Academic Librarianship, 41(4), 466-474. http://dx.doi.org/10.1016/j.acalib.2015.04.003

Seidman, I. (1998). Interviewing as qualitative research: A guide for researchers in education and the social sciences. New York: Teachers College Press.

Shao, X., Scherlen, A., Johnson, M., Xu, X., \& Hu, Y. (2013). Chinese students in American academic libraries: A survey of Chinese user satisfaction with US library experience. 
International Information \& Library Review, 45(1), 28-36.

http://dx.doi.org/10.1080/10572317.2013.10766369

Statistics Canada. (2011). Description for chart 6. Distribution of international and Canadian students, by field of study, Canada, 1992 and 2008. Retrieved from www.statcan.gc.ca/pub/81004-x/2010006/chrt-graph/desc/desc-6-eng.htm

Trew, F. (2006). Serving different constituencies: International students. In P. Dale, M. Holland \& M. Matthews (Eds.), Subject librarians: Engaging with the learning and teaching environment (pp. 149-172). Aldershot, Hants, England; Burlington, Vt.: Ashgate.

Yi, Z. (2007). International student perceptions of information needs and use. Journal of Academic Librarianship, 33(6), 666-673. http://dx.doi.org/10.1016/j.acalib.2007.09.003

Zhao, J., \& Mawhinney, T. (2014, June 15-18). Identifying challenges faced by Chinese undergraduate engineering students in acquiring information literacy skills - A report on survey findings. Paper presented at the American Society for Engineering Education, Indianapolis, IN. Retrieved from https://peer.asee.org/20578

\section{Appendix A - Participant information}

\begin{tabular}{l|l|l|l|l|l|l|l}
\hline \multicolumn{2}{l}{ Native Chinese-speaking participants } & \multicolumn{3}{l}{ Native English-speaking participants } \\
\hline Code & Gender & Program & $\begin{array}{l}\text { Year in } \\
\text { program }\end{array}$ & Code & Gender & Program & $\begin{array}{l}\text { Year in } \\
\text { program }\end{array}$ \\
\hline C01 & Female & Electrical & $2^{\text {nd }}$ year & E01 & Male & Materials & 1st year \\
\hline C02 & Male & Mechanical & $2^{\text {nd }}$ year & E02 & Male & Materials & 2nd year \\
\hline C03 & Male & Electrical & $2^{\text {nd }}$ year & E03 & Male & Materials & 2nd year \\
\hline C04 & Female & Materials & $2^{\text {nd }}$ year & E04 & Female & Mechanical 2nd year \\
\hline C05 & Male & Mechanical & $2^{\text {nd }}$ year & E05 & Male & Mechanical 2nd year \\
\hline C06 & Male & Mining & $1^{\text {st }}$ year & E06 & Male & Materials & 1st year \\
\hline C07 & Male & Mechanical & $1^{\text {st }}$ year & E07 & Male & Materials & 1st year \\
\hline C08 & Male & Materials & $1^{\text {st }}$ year & E08 & Male & Electrical & 1st year \\
\hline
\end{tabular}




\begin{tabular}{l|l|l|l|l|l|l|l}
\hline & & & & E09 & Male & Civil & 2nd year \\
\hline
\end{tabular}

\section{Appendix B - Sample interview questions}

General - How was your experience overall in completing your paper? How was the experience the same or different from papers you had researched and written before? What services would you have liked to make the researching and writing process easier?

Identify - How did you choose your topic? Was it difficult to select a topic?

Scope - How was your experience selecting a research database?

Plan - How was your experience creating a search strategy to use for searching for articles? You mentioned you had difficulty finding enough relevant information sources. Can you explain in more detail?

Gather - How was your experience locating the full text of journal articles? You mentioned that you gave up trying to find the full text. Can you explain further?

Evaluate - You mentioned you did not have difficulty determining the relevance of information sources that you found. How did you determine the relevance? Did you have difficulty determining if information was credible?

Manage - You mentioned you used EndNote but also added references manually. Can you explain further?

Present - How was your experience incorporating ideas from your readings into your paper? 